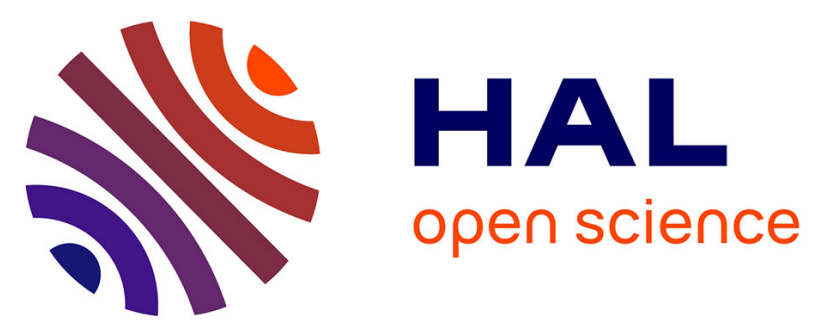

\title{
Herpesviruses In Respiratory Liquids Of Horses: Putative Implication In Airway Inflammation And Association With Cytological Features
}

Guillaume Fortier, Emmanuelle van Erck, Christine Fortier, Eric Richard, Didier Pottier, Stéphane Pronost, Fabien Misczack, Etienne Thiry, Pierre Lekeux

\section{To cite this version:}

Guillaume Fortier, Emmanuelle van Erck, Christine Fortier, Eric Richard, Didier Pottier, et al.. Herpesviruses In Respiratory Liquids Of Horses: Putative Implication In Airway Inflammation And Association With Cytological Features. Veterinary Microbiology, 2009, 139 (1-2), pp.34. 10.1016/j.vetmic.2009.04.021 . hal-00520653

\section{HAL Id: hal-00520653 https://hal.science/hal-00520653}

Submitted on 24 Sep 2010

HAL is a multi-disciplinary open access archive for the deposit and dissemination of scientific research documents, whether they are published or not. The documents may come from teaching and research institutions in France or abroad, or from public or private research centers.
L'archive ouverte pluridisciplinaire HAL, est destinée au dépôt et à la diffusion de documents scientifiques de niveau recherche, publiés ou non, émanant des établissements d'enseignement et de recherche français ou étrangers, des laboratoires publics ou privés. 


\section{Accepted Manuscript}

Title: Herpesviruses In Respiratory Liquids Of Horses:

Putative Implication In Airway Inflammation And Association

With Cytological Features

Authors: Guillaume Fortier, Emmanuelle van Erck, Christine

Fortier, Eric Richard, Didier Pottier, Stéphane Pronost, Fabien

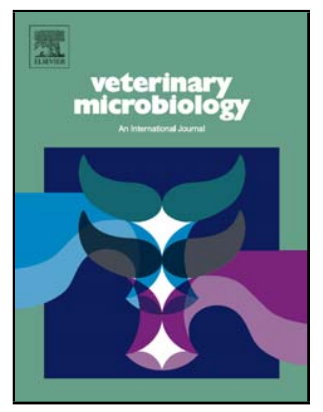

Misczack, Etienne Thiry, Pierre Lekeux

PII:

S0378-1135(09)00213-2

DOI:

doi:10.1016/j.vetmic.2009.04.021

Reference:

VETMIC 4425

To appear in:

Received date: $\quad$ 18-2-2009

Revised date: $\quad$ 31-3-2009

Accepted date: $\quad$ 14-4-2009

Please cite this article as: Fortier, G., van Erck, E., Fortier, C., Richard, E., Pottier, D., Pronost, S., Misczack, F., Thiry, E., Lekeux, P., Herpesviruses In Respiratory Liquids Of Horses: Putative Implication In Airway Inflammation And Association With Cytological Features, Veterinary Microbiology (2008), doi:10.1016/j.vetmic.2009.04.021

This is a PDF file of an unedited manuscript that has been accepted for publication. As a service to our customers we are providing this early version of the manuscript. The manuscript will undergo copyediting, typesetting, and review of the resulting proof before it is published in its final form. Please note that during the production process errors may be discovered which could affect the content, and all legal disclaimers that apply to the journal pertain. 


\title{
HERPESVIRUSES IN RESPIRATORY LIQUIDS OF HORSES: PUTATIVE IMPLICATION IN AIRWAY INFLAMMATION AND ASSOCIATION WITH CYTOLOGICAL FEATURES
}

Guillaume Fortier ${ }^{\text {a-b-* }}$, Emmanuelle van Erck ${ }^{\mathrm{b}}$, Christine Fortier ${ }^{\mathrm{a}}$, Eric Richard ${ }^{\mathrm{b}-\mathrm{c}}$, Didier Pottier ${ }^{\mathrm{d}}$, Stéphane Pronost ${ }^{\mathrm{a}}$, Fabien Misczack ${ }^{\mathrm{a}}$, Etienne Thiry ${ }^{\mathrm{e}}$, Pierre Lekeux ${ }^{\mathrm{b}}$.

${ }^{a}$ Frank Duncombe Laboratory, 14053 CAEN cedex 4, France.

${ }^{\mathrm{b}}$ Department of Functional Sciences, Physiology, ${ }^{\mathrm{e}}$ Department of Infectious and Parasitic Diseases, Virology and viral Diseases, Faculty of Veterinary Medicine, University of Liège, B-4000 LIEGE, Belgium.

${ }^{\mathrm{c}}$ CIRALE, 14430- Goustranville, France

${ }^{d}$ GRECAN, UFR des Sciences Pharmaceutiques, Université de Caen Basse-Normandie, 14000 Caen, France.

* Corresponding author: Guillaume Fortier, tel.: +332314719 19; fax: +33231471949.

email address: g.fortier@cg14.fr

\begin{abstract}
The objectives of this study were to estimate the prevalence and the potential role of equine herpesviruses (EHVs) detection in both bronchoalveolar lavage (BAL) and tracheal wash (TW). The population included a control group (CTL; $37 \mathrm{TW}$ and $25 \mathrm{BAL}$ ) and a pathological group (PAT; $259 \mathrm{TW}$ and $387 \mathrm{BAL}$ ), including horses either suffering from respiratory diseases including syndrome of tracheal inflammation, inflammatory airway disease, recurrent airway obstruction, or submitted to respiratory investigation because of exercise intolerance or poor performance. Each respiratory liquid was submitted to a standardised cytological analysis, mentioning the morphological abnormalities of exfoliated epithelial cells (ECAb) and ciliocytophthoria $(\mathrm{CCPh})$ as markers of potential viral infection, as well as PCR assays including a consensus PCR and virus-specific PCR for both equine alphaherpesviruses (EHV-
\end{abstract}


1; EHV-4) and gammaherpesviruses (EHV-2; EHV-5). The EHV infections were more prevalent in the TW of PAT group $(P=0.004)$, with the highest prevalence being for EHV-2 $(P=0.006)$. The EHV detection in BALs was not significantly different between groups. The EHVs detection in TW was correlated to the polymorphonuclear neutrophil (PMN) counts in the respiratory liquid but not with $\mathrm{CCPh}$ or $\mathrm{ECAb}$. $\mathrm{CCPh}$ or ECAb were associated with both consensus PCR and EHV-2 and EHV-5 virus-type PCR in the BAL only. The significant detection of EHVs in the TW of PAT group in association with the PMN increased counts could lead to further investigations about their putative role in equine syndrome of tracheal inflammation.

Keywords: ciliocytophthoria, respiratory disease, horse, herpesvirus, PCR, gammaherpesvirus 


\section{Introduction}

2 Respiratory diseases are a consensually recognised cause of wastage in the horse industry.

3 Among respiratory diseases, airway inflammation is the most prevalent clinical feature and is

4 largely encountered in the field. Recently, inflammatory airway disease (IAD) was redefined

5 as a clinical syndrome causing a significant elevation of polymorphonuclear neutrophil

6 (PMN) count in the bronchoalveolar lavage fluid (Couetil et al., 2007). Less is however

7 known about the syndrome of tracheal inflammation (STI) even if viruses, bacteria or fungi are suspected as potential actors of this local neutrophilia (Couetil et al., 2007). Modifications in the cytological profiles of BAL or TW have sometimes been evoked in case of viral diseases but without clear demonstration (Whitwell and Greet, 1984; Viel, 2002). Transient neutrophilia in respiratory liquids has been also described after viral exposure but cannot be interpreted as a specific profile (McGorum and Dixon, 1994; Sutton et al., 1998). On the other hand, ciliocytophthoria is a criteria used for the differential diagnosis of viral disease in human pathology, especially for respiratory or genital cytology (Papanicolaou et al., 1961). Whitwell and Greet (1984) also described this anomaly in cases of viral diseases and more particularly in those caused by herpesvirus in horses with tracheal inflammation and mucosal erosion. Pointing out the putative role of viruses in inflammatory airway diseases, Viel (2002) emphasized the need of incorporation of exfoliated epithelial cells (EEC) in the BAL cytological analysis.

Due to their high prevalence and their capability of latency in various sites, viruses and 21 particularly herpesviruses are frequently incriminated in equine poor performance syndromes (Wood et al., 2005). However, alphaherpesviruses such as equid herpesvirus 1 (EHV-1) or equid herpesvirus 4 (EHV-4) do not seem to be clearly associated with such syndromes

24 (Newton et al., 2003; Wood et al., 2005). The alphaherpesviruses are recognised as causative 25 agents of various epidemic diseases in the horse population (i.e; abortion, 
myeloencephalopathy) and as well as of upper respiratory tract infections, but equine gammaherpesviruses have been less studied and have been characterized (Agius and Studdert, 1994) and reclassified (Davison et al., 2009) only recently. Their real pathogenic significance remains unclear because of their frequent isolation in healthy horse populations and their high seroprevalence worldwide (Bell et al., 2006). In mice, equid herpesvirus 2 (EHV-2) DNA can be retrieved from the lungs 30 days after experimental exposure and infection (Borchers et al., 2002). In foals or young race horses, this virus has been shown to induce conjunctivitis and mild respiratory diseases, (Bell et al., 2006). In addition, equid herpesvirus 5 (EHV-5) has been recently associated with equine pulmonary multinodular syndrome (Williams et al., 2007).

Performing both consensus PCR and virus-specific PCR assays, the purposes of this study were (1) to precise the DNA prevalence of EHV-1, 2, 4 and 5 in respiratory liquids of horses suffering from various respiratory diseases and compare it to a control group, and (2) to determine if particular cytological profiles of the sampled liquids could be associated with herpesviruses detection and to investigate within the different groups the correlation between EHVs detection and neutrophilia or epithelial cells abnormalities in both the TW and the BAL.

\section{Materials and methods}

\subsection{Horse population and respiratory liquids}

The study included 708 samples (647 horses aged 18 months - 13 years; Table 1) of various breeds and/or disciplines (Standardbred, Thoroughbred, Endurance and French saddle horses) harvested between October 2006 and February 2008. Horses from the control group (CTL) were referred to a sports medicine facility (CIRALE, Goustranville, France) for routine clinical and fitness follow-up using standardised protocols. Thorough clinical and 
complementary exams were systematically performed, including haematological and biochemical evaluation at rest and post-exercise, Doppler echocardiography, standardised exercise tests on both treadmill and racetrack, locomotor evaluation, high-speed treadmill video-endoscopy of the upper respiratory tract, and collection of respiratory liquids including TW and BAL. Each CTL horse was free of any abnormality for all these clinical investigations, and particularly a scoring mucus $\leq 2$ (Gerber et al., 2004), no signs of infection/inflammation at the haemato-biochemical evaluation (Couetil et al., 2007) and both TW and BAL cytological values within proposed references (Robinson, 2003). The pathological group (PAT) was composed of horses with signs of various respiratory disorders or "poor performance syndrome" and originated from 28 veterinary practices located close to training yards or race tracks in the Normandy or Ile de France regions. To be included, at least one of the following criteria had to be detected by the clinician: coughing, scoring mucus $>2$, TW or BAL neutrophilia, or poor performance suspected by the practitioner to be due at least partly to respiratory dysfunctions. Any horse exhibiting dyspnoea at the moment of sampling or clinical signs of either acute viral (i.e. serous nasal discharge, hyperthermia, ...) or bacterial infection (i.e. purulent nasal discharge, leukocytosis, ...), were excluded from the study.

\subsection{Samples processing and cytological analysis}

Each practice or referring veterinarian was expected to follow the main recommendations regarding sampling and shipment of TW or BAL (Viel, 2002; Pickles et al., 2002; Malikides et al., 2007). Samples of each group were excluded if a set of quality criteria was not met (i.e presence of squamous pharyngeal cells, cell degradation, contaminating bacterial flora or lack of historical information). Aliquots of respiratory liquids were placed in EDTA- and serum tubes and respectively submitted for cytology and virology. May Grunwald Giemsa stain was applied to slides previously prepared by smooth cytocentrifugation $(75 \mathrm{x} g, 10 \mathrm{~min})$ using a 
Cytospin (Shandon-Thermoscientific, Waltham, MA, USA). Differential cell counts were performed by counting an average of 300 cells and the results of each cell type were expressed as a percentage of the total nucleated cells. Presence of exfoliated epithelial cells (EEC) were noted and defined as either normal or presenting morphological abnormalities (ECAb) when free cilia, ciliated plates or detached ciliated tufts were found in the liquid (Sutton et al., 1997; Viel, 2002) or ciliocytophthoria (CCPh) when the previous criteria was accompanied by cytoplasmic or nuclear modifications (Whitwell and Greet, 1984; Freeman et al., 1985). The EEC were initially included in the sample cell counts to determine if there were any significant differences in proportion between the CTL and the PAT group. Thereafter, EEC were excluded from the differential cell counts but ECAb anb CCPh were taken into account in the statistical analysis as "present" or "absent". Hematological and biochemical tests were performed with an Advia 120 (Bayer) and a Rx Imola (Randox,) 2.3 Nucleic acids extraction and PCR assays

Respiratory liquids were centrifuged at $2000 \times \mathrm{g}, 4{ }^{\circ} \mathrm{C}$, during $15 \mathrm{~min}$, and pellets were homogenised with $500 \mu \mathrm{l}$ of supernatant. DNA was extracted from $140 \mu \mathrm{l}$ of each sample, using the QIAamp DNA Mini Kit (Qiagen, France) according to the manufacturer's instructions, and eluted in a $50 \mu \mathrm{l}$ final volume. Concentrated DNA was stored at $-80{ }^{\circ} \mathrm{C}$ until used. All extraction included a negative control where respiratory liquid was replaced with distilled water and a positive control.

The five PCR assays systematically carried out on each sample for this study are summarized in table 2. A consensus herpesvirus PCR assay was carried out as previously described by Leon et al. (2008). EHV-2 was detected by amplification of a sequence encoding a product homologous to human interleukin-10 (Leon, personal communication 2008; adapted from Borchers and Frolich, 1997) whereas EHV-5 was detected by a virus-specific EHV-5 PCR assay described by Dynon et al. (2001). Classical PCRs (consensus PCR and virus-specific 
101 EHV-2 and EHV-5 PCR) were performed with pure Taq Ready to Go PCR beads (Amersham

102 Biosciences, Europe $\mathrm{GmbH}$, France); the final concentrations of each primer were $1 \mu \mathrm{M}$ 103 consensus PCR, $1 \mu \mathrm{M}$ EHV-2 and $800 \mathrm{nM}$ EHV-5. Classical PCRs were performed on 104 GeneAmp PCR System 9700 (Applied Biosystems). Virus-specific real-time PCRs were 105 performed as described by Diallo et al. (2007). Each test was used as a simplex assay in a 106 total volume of $25 \mu \mathrm{l}$ containing $2 \mathrm{x}$ Taqman Universal PCR Master Mix (Applied 107 Biosystems, France), $1 \mu \mathrm{M}$ of each primer and the optimum concentration of probe (between 108100 and $400 \mathrm{nM}$ as determined after titration). Real time amplifications were performed on 109 Step One Real-Time PCR system (Applied Biosystems). Each different PCR test included a 110 negative control where DNA was replaced with distilled water and a specific positive control 111 where DNA from each virus was amplified. DNA from American Type Culture Collection 112 reference strains for EHV-1 (Kentucky reference strain, KyA), EHV-2 (LK strain) and EHV-4 113 strain 405/76 and DNA from our laboratory for EHV-5 (Fortier et al. 2008, in press).

114 Positive samples by consensual PCR which were negative with each virus-specific PCR 115 assays (EHV-1, 2, 4 and 5), were sequenced after extraction of the PCR product from agarose 116 using the QIAquick gel extraction kit (Qiagen, France). Both sense and anti-sense strands of 117 the PCR products were sequenced (Biofidal, France). The nucleotide sequences were 118 assembled and manually edited (CodonCode Aligner), and consensus PCR sequences were 119 analysed for similarities on the National Center for Biotechnology Information (NCBI) 120 website using databases and the Basic Local Alignment Search Tool program (BLASTn). 2.4 Statistical analysis

123 Differences in the results between the groups were compared using a Fisher's exact test. A

124 Cochran Armitage trend test was used to evaluate the trend between PMN cell counts and 125 herpesviruses DNA detection in the samples. According to the percentage of PMNs in the 
126 liquids, PMN results were conventionally distributed into 6 different classes, from 0 to $20 \%$,

127 from 21 to $40 \%$, from 41 to $60 \%, 61$ to $80 \%$ and $>80 \%$.Odds ratio (OR) were performed to 128 evaluate the risk of being in the PAT group when herpesvirus DNA was detected. All tests 129 were performed on SAS System (Cary, NC, USA). $P$ values $<0.05$ were considered 130 significant.

\section{Results}

3.1. PCR assays in the respiratory fluids

In the TW of the CTL group, EHV-2 and EHV-4 were detected by virus-specific PCR whereas EHV-1 and EHV-5 were not. In this group, two samples were positive using the consensus PCR but were not confirmed by the specific tests and no clear identification was achieved using the sequencing. In the PAT group, all the targeted viruses were detected. Using PCR, 114 and 112 PAT TW were positive by virus-specific and consensus PCRs respectively (Table 3); 2 samples were detected positive for both EHV-2 and EHV-5. The

140 prevalence of herpesviruses in the TW was significantly higher in the PAT group $(P=0.004)$.

141 Detection of EHV-2 was also higher in the PAT group compared to the CTL group 142 ( $P=0.006)$. The highest level of detection for both groups was found for EHV-2, with 11\% and 33\% for the CTL group and PAT group respectively. In the BAL, only EHV-2 and EHV4 were detected in the CTL group (Table 3), whereas in the PAT group all viruses were detected, as in the TW. The prevalence of these viruses in BAL was not significantly different

146 between groups. The highest level of detection for both groups was found for EHV-2, with $14736 \%$ and $21 \%$ for the CTL group and PAT group respectively. Whatever the group and 148 sample, EHV-2 was the most frequently detected strain. A double detection (EHV-2 and 149 EHV-4) was found in two BAL samples of the PAT group. Among the 708 samples, Asinine 150 herpesvirus 5 (AHV-5) was identified in 24 PAT liquids (16 in the BAL and 8 in the TW of 
151 by sequencing the amplified fragment of the consensus PCR (Table 3 and 4). Among them, a

152 mild positive result was obtained in 8 samples at the second run using the virus-specific EHV-

1535 PCR. Only consensus PCR positive results were taken into account for the statistical

154 analysis but not virus type specific results. For the two real-time PCR (EHV-1, EHV-4) the

155 cycle threshold $\left(\mathrm{C}_{\mathrm{t}}\right)$ was mentioned for each analysis. In the TW of PAT group, the $\mathrm{Ct}$ range

156 was 22 - 42 for EHV-4 and 36.5 - 38.4 for EHV-1, whereas the $C_{t}$ was 38 for the only EHV-4

157 positive sample in the CTL group.

158 In the BAL of the PAT group, the $\mathrm{C}_{\mathrm{t}}$ range was $34-44$ for EHV-4 and $35-40.5$ for EHV-1,

159 whereas the $\mathrm{C}_{t}$ was 39 for the only EHV-4 positive sample in the CTL group.

160 Inclusion in the PAT group was positively and significantly associated with the detection of

161 herpesviruses by both consensus PCR (odds ratio $=3.26,95 \%$ C.I $=1.38-7.04$ ) and EHV-2

162 specific PCR assay (odds ratio $=4.03$, 95\% C.I $=1.37-11.74$ ). No significant association was observed for any other herpesvirus neither in the TW nor in the BAL.

\subsection{Association between groups, viral detection and cytology of the liquids}

166 The proportion of EEC in the BAL (0.7\% vs $2.7 \%)$ and TW (15.6\% vs $12.8 \%)$ were not

167 significantly different between the CTL group and the PAT group and ranged with normal 168 values (Derksen et al., 1989). Percentages of CCPh or ECAb were not significantly associated

169 with groups (Table 4). No morphological abnormality was detected among the BAL epithelial 170 cells (ECAb and CCPh) in the CTL group. The proportion of CCPh was increased in the PAT 171 group, but not significantly $(P=0.32)$.

172 As described in Table 5, the presence of one of the two positive criteria for epithelial cell 173 alterations (ECAb, $\mathrm{CCPh}$ ) was significantly associated with herpesvirus DNA detection for 174 EHV-2 and EHV-5, but in the BAL only. No other significant association was found for 175 EHV-4 in either liquid neither for any other herpesvirus in the TW. No significant association 
were found between herpesviruses detection (in TW or BAL) and either lymphocytes, giant cells, mast cells, eosinophils, macrophages, or haemosiderophages. In the TW only, a significant association between PMN counts level and DNA detection with the consensus PCR or the EHV-2 virus-type specific PCR was observed (Table 6), whereas a tendency, at the limit of significance, was found for EHV-4 detection $(\mathrm{P}=0.05)$. In the TW, the highest percentage of EHV-2 detection was in the sub-group of 40-60\% of PMN and in the sub-group $80-100 \%$ of PMN for EHVs with the consensus PCR. The mean level of PMN was higher when herpesvirus DNA was detected with consensus PCR $(P=0.003)$ or EHV-2 specific PCR $(P=0.04)$. The results were not significant using EHV-5, EHV-1 and EHV-4. The trend test was not significant for any herpesvirus in the BAL.

No significant trend was found between ciliocytophthoria and the PMN cell counts in either BAL or TW, meanwhile the highest percentage of $\mathrm{CCPh}$ was found in the $40-60 \% \mathrm{PMN}$ class for TW.

\section{Discussion}

The precise role of equine herpesviruses in subclinical respiratory diseases has been documented mainly through the results of serologic assays or naso-pharyngeal sampling studies in young racing horses (Wood et al., 2005).

Previous studies evaluating viral causes of respiratory diseases in young horses in training mainly focused on alphaherpesviruses, which remain the most worldwide studied herpesviruses in the equine population (Newton et al., 2003; Wood et al., 2005). Gammaherpesviruses were seldom included and information lacked regarding their implication in larger populations of horses suffering from various respiratory disorders. Our study aimed at investigating this missing information by undertaking a systematic DNA detection of herpesviruses in TW and BAL respiratory liquids of horses suspected of 
respiratory affections. Serologic tools were not implemented for EHV detection as they may not be a reliable method for investigating viral reactivation because of cross-reaction, poor humoral response and lack of seroconversion due to repeated exposures and vaccination. One of the limits in the PCR strategy used in the present study is that it could not allow discrimination between latent, non replicating and lytic states of the detected herpesviruses (Pusterla et al., 2008).

Among the alphaherpesviruses detected in the present study, EHV-4 was much more prevalent than EHV-1, and this can be related to its particular role in clinical respiratory disorders in the field. Even if the $C_{t}$ values obtained for EHV-1 and EHV-4 were in previously described ranges (Diallo et al., 2007), taking into account the artificial dilution due to the sampling method for respiratory liquids, the detection of latent viruses could not be avoided. EHV-4 were sometimes retrieved from liquids with low $C_{t}$ (high viral load) when a history of infectious disease of suspected viral origin was mentioned by the practitioner.

Equine herpesvirus DNA detection was clearly different in the two groups of horses, especially in the TW.

The high prevalence of EHV-2 and EHV-5 DNA shown in our study's pathological group is in accordance with previous observations, indicating their frequent detection in nasal swabs, yet from horses without clear clinical signs (Bell et al., 2006). Only few reports exist on EHV-2 and EHV-5 and airway diseases of horses (Allen and Murray, 2004) and most reports concern alphaherpesviruses and relate experimental viral infections with these strains in a lytic phase (Sutton et al., 1998).

EHV-2 is known to be latent in lymphocytes (Drummer et al., 1996) or macrophages (Borchers et al., 2002), however no correlation was found between DNA detection and lymphocyte or macrophage counts in both TW and BAL cytological analysis (data not shown). Detection of EHV-2 in the BAL of the CTL group, without EEC abnormalities 
226 (ECAb or $\mathrm{CCPh}$ ) could be due to latency states of the virus in the lymphocytes or macrophages of these liquids. Identification of AHV-5 by sequencing the PCR product of the consensus PCR, with only a low percentage of confirmation by virus-specific PCR tests (EHV-5) was also surprising. No history of concomitant grazing or neighbouring between horses and donkeys could be proven retrospectively. We hypothesised that the difference in detection between the consensus PCR and virus-type specific EHV-5 PCR could have been a consequence of the two different PCR methods, a nested PCR assay versus a standard PCR assay for EHV-5. The AHV-5 matching assessed with Genbank could be due to a lack of reported sequences for the EHV-5 virus. The EHV-5 DNA detection was therefore probably underestimated in the present work, mainly in the BAL samples.

Herpesvirus DNA detection was then considered in the light of other potential criteria of viral infection such as clinical suspicion or expression (group), epithelial cell morphological criteria or cytological neutrophilic profiles in the respiratory samples. The interpretation of high exfoliated epithelial cell counts or abnormal morphology in TW or BAL analysis is a recurrent preoccupation of clinicians and searchers and is often considered as a result of mechanical trauma during sampling procedures, leading to a wide range of published epithelial cell percentages between studies (Derksen et al., 1989). More interesting is the analysis of cell morphology during cytological examination, which takes into account the presence and integrity of the ciliae, nuclear damage (Whitwell and Greet, 1984; Viel, 2002),

245 or the better defined ciliocytophthoria (Papanicolaou et al., 1961; Freeman et al., 1985).

246 The disparity between results of the TW and BAL in investigations of respiratory disorders 247 and perhaps in virus DNA detection could be attributed to the intrinsic differences of these 248 two liquids. The trachea is a "crossroad" connecting the upper and lower respiratory tracts 249 and the TW is therefore recognised as potentially contaminated and of variable cytological 250 quality compared to BAL, even in a healthy population. For this reason, IAD or RAO are 
exclusively based on a BAL cytological diagnosis. This was recently confirmed by Couetil et

252 al.(2007) who suggested that TW should be studied more in depth in terms of the mechanisms

253 inducing tracheal inflammation (i.e; viruses, bacteria, fungi...). In the present study,

254 ciliocytophthoria $(\mathrm{CCPh})$ or epithelial cell abnormalities (ECAb) did not seem to be sensitive

255 norspecific "herpesvirus markers" in TW, whereas in the BAL theses epithelial alterations

256 were significantly linked to the presence of both EHV-2 and EHV-5 whatever the group

257 considered.

258 Detection of other viruses such as rhinovirus or influenza virus was not achieved in this study.

259 However these viruses are known to potentially induce mild to severe airway inflammation in

260 horses even a long time after an initial exposure (Willoughby et al., 1992; Sutton et al., 1997).

261 Epithelial cell erosion in the trachea $(\mathrm{CCPh}$ or ECAb) may also be induced by these viruses

262 explaining the lack of specificity the chosen criteria for positives samples with herpesviruses

263 specifically. The tracheobronchial lymphoid associated tissues represent major latency sites

264 (Allen and Murray, 2004), almost exclusive for herpesviruses and less exposed to other

265 viruses. Epithelial cell damage is therefore more likely to be associated to herpesviruses

266 pathogenicity. During an EHV-2 experimental infection, Borchers et al. (1998) retrieved

267 infectious viruses in nasal or ocular swabs, and viral DNA in the lung and lymphoid tissues

268 after an induced reactivation with dexamethasone (30 days post infection). One could also

269 hypothesize that reactivation can take place after various stressful conditions (intense

270 exercise, competition, transport,...) or corticotherapy and lead to viral shedding in the

271 respiratory tract.

272 Conversely, in the TW, herpesvirus DNA detection was significantly associated with

273 increased neutrophil counts and group. The causative effect of herpesviruses on inflammation

274 after viral exposure remains to be elucidated, even being experimentally showed with EHV-1

275 (Smith et al., 2000). One of the EHV-2 G protein coupled receptor (GPCR) is a receptor for 
interleukine 8 (IL-8) and the EHV-2 open reading frame E7 codes for IL-10, which is an

277 immunosuppressive cytokine. The chemo-attractant effect of IL-8 for PMNs has previously 278 been described in several clinical or experimental situations (Franchini et al., 2000). EHV-2

279 can be retrieved in the lung several weeks post infection in mice (Borchers et al., 2002). As

280 EHV-2 replication occurs following the delivery of virus or virus genome by a cell-to-cell

281 contact mechanism from lymphocytes to fully permissive epithelial cells, the detection of 282 viral DNA could be associated with immunomodulation of the host pathway, epithelial cells 283 modifications and neutrophilic recruitment a long time after natural exposure (Drummer et al., 284 1996). Schlocker et al. (1995) suggested early on that EHV-2 could play a role in equine chronic pulmonary disease. The significant association between $\mathrm{CCPh}$ or ECAb and DNA detection could also be explained by such a particular viral physiopathology.

287 Genomic variations (Browning and Studdert, 1987; Sharp et al., 2007) and concomitant 288 infections with several field strains of EHV-2 have been demonstrated (Bell et al., 2006) and 289 may determine a graduation in the clinical expression of the disease.

\section{Conclusions}

291 The purposes of this study were (1) to precise the DNA prevalence of four EHVs in 292 respiratory liquids of horses suffering from various respiratory diseases in comparison with a control group, (2) to determine if particular cytological profiles of the liquids were associated with EHVs detection, by investigating, in the different groups, the correlation between EHVs detection and neutrophilia or epithelial cells abnormalities and/or ciliocytophthoria. Herpesviruses DNA was more frequently detected in the TW of the PAT group and associated 297 with liquid neutrophilia. Among these viruses, EHV-2 was the most prevalent. No specific epithelial cells profile could be found in association with viral DNA detection in the TW but ciliocytophthoria or epithelial cells abnormalities were interesting features of the BAL

300 significantly associated with the detection of EHV-2 and EHV-5. As respiratory tract 
301 inflammation has already been demonstrated during experimental infection with EHV-1 or

302 influenza virus in the horse, equine herpesviruses and particularly gammaherpesviruses may

303 be implicated in the syndrome of tracheal inflammation.

304 Even if the precise status of the viral infection (lytic, non replicating, latent) could not be 305 elucidated through the PCR assays strategy used in this study, an experimental infection with 306 EHV-2 in "naïve" horses or induced reactivation should give more information about the 307 potential role of this gammaherpesvirus in the horse. Other tools, such as interferon gamma 308 detection or cytokine profile of the liquids could be useful to better understand or clarify the 309 association with virus DNA detection and cytology of the liquids, particularly the TW.

\section{Acknowledgements}

312 The authors gratefully acknowledge the practitioners who participated to this study. The project received financial support from the Conseil general du Calvados and the French national Studs (Haras Nationaux).

\section{References}

Agius, C.T., Studdert, M.J., 1994. Equine herpesviruses 2 and 5: comparisons with other members of the subfamily gammaherpesvirinae. Adv.Virus Res. 44, 357-379.

Allen, G.P. and Murray, J.T., 2004. Equid herpesvirus 2 (EHV-2) and Equid herpesvirus (EHV-5). In: Coetzer,J.; Thomson,G.; Tustin,R. (Eds.), Infectious disease of livestock. Oxford Press, Capetown, UK, pp. 860-868. mares and their foals. Vet.Microbiol. 116, 249-257. 
Borchers, K., Brackmann, J., Kershaw, O., 2002. The mouse is not permissive for equine herpesvirus 2 (EHV-2), however viral DNA persisted in lung and spleen depending on the inoculation route. Arch.Virol. 147, 1437-1444.

Borchers, K., Frolich, K., 1997. Antibodies against equine herpesviruses in free-ranging mountain zebras from Namibia. J.Wildl.Dis. 33, 812-817.

Borchers, K., Wolfinger, U., Ludwig, H., Thein, P., Baxi, S., Field, H.J., Slater, J.D., 1998. Virological and molecular biological investigations into equine herpes virus type 2 (EHV-2) experimental infections. Virus Res. 55, 101-106.

Browning, G.F., Studdert, M.J., 1987. Genomic heterogeneity of equine betaherpesviruses. J.Gen.Virol. 68, 1441-1447. Lavoie, J.P., 2007. Inflammatory airway disease of horses. J.Vet.Intern.Med. 21, 356-361.

Davison, A.J., Eberle, R., Ehlers, B., Hayward, G.S., McGeoch, D.J., Minson, A.C., Pellett, P.E., Roizman, B., Studdert, M.J., Thiry, E., 2009. The order Herpesvirales. Arch.Virol. 154, 171-177.

Derksen, F.J., Brown, C.M., Sonea, I., Darien, B.J., Robinson, N.E., 1989. Comparison of transtracheal aspirate and bronchoalveolar lavage cytology in 50 horses with chronic lung disease. Equine Vet.J. 21, 23-26.

Diallo, I.S., Hewitson, G., Wright, L., Rodwell, B.J., Corney, B.G., 2006. Detection of equine herpesvirus type 1 using a real-time polymerase chain reaction. J.Virol.Methods 131, 92-98.

Diallo, I.S., Hewitson, G., Wright, L.L., Kelly, M.A., Rodwell, B.J., Corney, B.G., 2007. and equid herpesvirus 4 (EHV-4). Vet.Microbiol. 123, 93-103.

Drummer, H.E., Reubel, G.H., Studdert, M.J., 1996. Equine gammaherpesvirus 2 (EHV2) is latent in B lymphocytes. Arch.Virol. 141, 495-504.

355 Dynon, K., Varrasso, A., Ficorilli, N., Holloway, S., Reubel, G., Li, F., Hartley, C., Studdert, M., Drummer, H., 2001. Identification of equine herpesvirus 3 (equine coital exanthema virus), equine gammaherpesviruses 2 and 5, equine adenoviruses 1 and 2, equine arteritis virus and equine rhinitis A virus by polymerase chain reaction. Aust.Vet.J. 79, 695-702.

359 Fortier, G., Pronost, S., Miszczak, F., Fortier, C., Leon, A., Richard, E., Van Erck, E., Thiry,

360 E., Lekeux, P., 2008. Identification of equid herpesvirus-5 in respiratory liquids: A

361 retrospective study of 785 samples taken in 2006-2007. Vet J . in press

362 Franchini, M., Gill, U., von, F.R., Bracher, V.D., 2000. Interleukin-8 concentration and 363 neutrophil chemotactic activity in bronchoalveolar lavage fluid of horses with chronic 364 obstructive pulmonary disease following exposure to hay. Am. J. Vet. Res. 61, 1369-1374.

365 Freeman, K.P., Roszel, J.F., Slusher, S.H., 1985. Inclusions in equine cytologic specimens. 366 J.Am.Vet.Med.Assoc. 186, 359-364. 
Gerber, V., Straub, R., Marti, E., Hauptman, J., Herholz, C., King, M., Imhof, A., Tahon, L., Robinson, N.E., 2004. Endoscopic scoring of mucus quantity and quality: observer and horse variance and relationship to inflammation, mucus viscoelasticity and volume. Equine Vet. J. 36, 576-582. Leon, A., Fortier, G., Fortier, C., Freymuth, F., Tapprest, J., Leclercq, R., Pronost, S., 2008. 20-29.

Malikides, N., Hughes, K.J., Hodgson, J.L., 2007. Comparison of tracheal aspirates before and after high-speed treadmill exercise in racehorses. Aust.Vet.J. 85, 414-419.

McGorum, B.C., Dixon, P.M., 1994. The analysis and interpretation of equine bronchoalveolar lavage fluid (BALF) cytology. Equine vet.Educ. 6, 203-209.

Newton, J.R., Wood, J.L., Chanter, N., 2003. A case control study of factors and infections associated with clinically apparent respiratory disease in UK Thoroughbred racehorses. Prev.Vet.Med. 60, 107-132.

Papanicolaou, G., Bridges, E., Railey, C., 1961. Degeneration of the ciliated cells of the bronchial epithelium (ciliocytophthoria) in its relation to pulmonary disease. Am Rev.Respir.Dis. 83, 641-659.

Pickles, K., Pirie, R.S., Rhind, S., Dixon, P.M., McGorum, B.C., 2002. Cytological analysis of equine bronchoalveolar lavage fluid. Part 3: The effect of time, temperature and fixatives. Equine Vet.J. 34, 297-301.

Pusterla, N., Mapes, S., Wilson, W.D., 2008. Use of viral loads in blood and nasopharyngeal secretions for the diagnosis of EHV-1 infection in field cases. Vet.Rec. 162, 728-729.

Robinson, N.E., 2003. Inflammatory airway disease: defining the syndrome. Conclusions of the Havemeyer workshop. Equine Vet. Educ.15, 61-63.

391 Schlocker, N., Gerber-Bretscher, R., von Fellenberg, R., 1995. Equine herpesvirus 2 in pulmonary macrophages of horses. Am.J.Vet.Res. 56, 749-754.

Sharp, E.L., Farrell, H.E., Borchers, K., Holmes, E.C., Davis-Poynter, N.J., 2007. Sequence analysis of the equid herpesvirus 2 chemokine receptor homologues E1, ORF74 and E6 demonstrates high sequence divergence between field isolates. J.Gen.Virol. 88, 2450-2462.

396 Smith, K.C., Whitwell, K.E., Mumford, J.A., Hannant, D., Blunden, A.S., Tearle, J.P., 2000. Virulence of the V592 isolate of equid herpesvirus-1 in ponies. J.Comp Pathol. 122, 288-297.

398 Sutton, G.A., Viel, L., Carman, P.S., Boag, B.L., 1997. Study of the duration and distribution 399 of equine influenza virus subtype 2 (H3N8) antigens in experimentally infected ponies in 400 vivo. Can.J.Vet.Res. 61, 113-120.

401 Sutton, G.A., Viel, L., Carman, P.S., Boag, B.L., 1998. Pathogenesis and clinical signs of 402 equine herpesvirus-1 in experimentally infected ponies in vivo. Can.J.Vet.Res. 62, 49-55.

403 VanDevanter, D.R., Warrener, P., Bennett, L., Schultz, E.R., Coulter, S., Garber, R.L., Rose, 404 T.M., 1996. Detection and analysis of diverse herpesviral species by consensus primer PCR. 405 J.Clin.Microbiol. 34, 1666-1671. 
Viel, L., 2002. Significance of bronchoalveolar cytology in inflammation airway disease of 407 horse. In:Hoffmann A., Robinson N. E. Wade J. F. Eds. (Eds), Inflammation airway disease. 408 Havemeyer Foundation Monograph series No 9, Boston, USA, 52-55.

409 Whitwell, K.E., Greet, T.R., 1984. Collection and evaluation of tracheobronchial washes in 410 the horse. Equine Vet.J. 16, 499-508.

411 Williams, K.J., Maes, R., del, P.F., Lim, A., Wise, A., Bolin, D.C., Caswell, J., Jackson, C., 412 Robinson, N.E., Derksen, F., Scott, M.A., Uhal, B.D., Li, X., Youssef, S.A., Bolin, S.R., 413 2007. Equine multinodular pulmonary fibrosis: a newly recognized herpesvirus-associated 414 fibrotic lung disease. Vet.Pathol. 44, 849-862.

415 Willoughby, R., Ecker, G., McKee, S., Riddolls, L., Vernaillen, C., Dubovi, E., Lein, D., 416 Mahony, J.B., Chernesky, M., Nagy, E., 1992. The effects of equine rhinovirus, influenza 417 virus and herpesvirus infection on tracheal clearance rate in horses. Can.J.Vet.Res. 56, 115418121.

419 Wood, J.L., Newton, J.R., Chanter, N., Mumford, J.A., 2005. Association between respiratory 420 disease and bacterial and viral infections in British racehorses. J.Clin.Microbiol. 43, 120-126. 
Table 1

Description of the studied population

\begin{tabular}{ccccc}
\hline & \multicolumn{2}{c}{ Control group (CTL) } & \multicolumn{2}{c}{ Pathological group (PAT) } \\
\cline { 2 - 5 } & $\begin{array}{c}\text { Tracheal washes } \\
\text { (TW) }\end{array}$ & $\begin{array}{c}\text { Bronchoalveolar lavages } \\
\text { (BAL) }\end{array}$ & $\begin{array}{c}\text { Tracheal washes } \\
\text { (TW) }\end{array}$ & $\begin{array}{c}\text { Bronchoalveolar lavages } \\
\text { (BAL) }\end{array}$ \\
\hline $\begin{array}{c}\text { Number of } \\
\text { samples }\end{array}$ & 37 & 25 & 259 & 387 \\
\hline $\begin{array}{c}\text { Age (years) } \\
\text { (mean } \pm \text { s.d. })\end{array}$ & $5.6 \pm 2.9$ & $6.3 \pm 3.05$ & $5.8 \pm 2.2$ & $5.4 \pm 3.4$ \\
\hline $\begin{array}{c}\text { PMNs count (\%) } \\
\text { (mean } \pm \text { s.d. })\end{array}$ & $10.4 \pm 6.9$ & $5.7 \pm 2.9$ & $57.1 \pm 34.7^{*}$ & $32.6 \pm 29.1^{*}$ \\
\hline
\end{tabular}

PMN: Polymorphonuclear neutrophils

* Statistically different from the corresponding CTL sample $(\mathrm{P}<0.0001)$ 
Table 2

Characteristics of the PCR assays used for the detection of equine herpesviruses.

\begin{tabular}{|c|c|c|c|c|c|c|c|c|}
\hline PCR assay & Target gene & Primer and probe sequences $\left(5^{\prime}-3^{\prime}\right)$ & & ication $\mathbf{p}$ & ram & $\begin{array}{l}\text { Product size } \\
\text { (bp) }\end{array}$ & PCR type & References \\
\hline $\begin{array}{l}\text { Consensual } \\
\text { herpes }\end{array}$ & DNA pol & $\begin{array}{l}\text { DFA: + GAYTTYGCNAGYYTNTAYCC } \\
\text { ILK: + TCCTGGACAAGCAGCARNYSGCNMTNAA } \\
\text { KG1: - GTCTTGCTCACCAGNTCNACNCCYTT } \\
\text { TGV: + TGTAACTCGGTGTAYGGNTTYACNGGNGT* } \\
\text { IYG: - CACAGAGTCCGTRTCNCCRTADAT* }\end{array}$ & $\begin{array}{l}94^{\circ} \mathrm{C} \\
94^{\circ} \mathrm{C} \\
46^{\circ} \mathrm{C} \\
72^{\circ} \mathrm{C} \\
72^{\circ} \mathrm{C}\end{array}$ & $\begin{array}{l}5 \mathrm{~min} \\
30 \mathrm{sec} \\
1 \mathrm{~min} \\
1 \mathrm{~min} \\
10 \mathrm{~min}\end{array}$ & $\mathrm{x} 45$ & $215-315$ & $\begin{array}{l}\text { Classical } \\
\text { Nested }\end{array}$ & $\begin{array}{c}\text { Van Devanter et al. } \\
\text { (1996) }\end{array}$ \\
\hline EHV1 & $\mathrm{gB}$ & $\begin{array}{l}\text { EHV1F1: + CATGTCAACGCACTCCCA } \\
\text { EHV1R1: - GGGTCGGGCGTTTCTGT } \\
\text { EHV1MGBPROBE: } 6 \text { FAM-CCCTACGCTGCTCC-MGB-NFQ }\end{array}$ & $\begin{array}{l}95^{\circ} \mathrm{C} \\
95^{\circ} \mathrm{C} \\
64^{\circ} \mathrm{C}\end{array}$ & $\begin{array}{l}10 \mathrm{~min} \\
15 \mathrm{sec} \\
1 \mathrm{~min}\end{array}$ & x50 & 63 & Real-time & Diallo et al.(2006) \\
\hline EHV2 & $\begin{array}{l}\text { « human } \\
\text { interleukin } 10 \\
\text { homologous } \\
\text { sequence }\end{array}$ & $\begin{array}{l}\text { EHV2pS: + AACTCCCATCCCCAGAAGAC } \\
\text { EHV2pAS: - TGTTTCCTCGCTAACCAACC }\end{array}$ & $\begin{array}{l}95^{\circ} \mathrm{C} \\
94^{\circ} \mathrm{C} \\
60^{\circ} \mathrm{C} \\
72^{\circ} \mathrm{C} \\
72^{\circ} \mathrm{C}\end{array}$ & $\begin{array}{l}15 \mathrm{~min} \\
30 \mathrm{sec} \\
1 \mathrm{~min} 30 \\
1 \mathrm{~min} 30 \\
10 \mathrm{~min}\end{array}$ & $\mathrm{x} 45$ & 245 & $\begin{array}{l}\text { Classical } \\
\text { One step }\end{array}$ & $\begin{array}{l}\text { Leon (personal } \\
\text { communication } \\
\text { 2008) }\end{array}$ \\
\hline EHV4 & $\mathrm{gB}$ & $\begin{array}{l}\text { EHV4F1: + GGGCTATTGGATTACAGCGAGAT } \\
\text { EHV4R1: - TAGAATCGGAGGGCGTGAAG } \\
\text { EHV4MGBPROBE: VIC-CAGCGCCGTAACCAG-MGB-NFQ }\end{array}$ & $\begin{array}{l}95^{\circ} \mathrm{C} \\
95^{\circ} \mathrm{C} \\
64^{\circ} \mathrm{C}\end{array}$ & $\begin{array}{l}10 \mathrm{~min} \\
15 \mathrm{sec} \\
1 \mathrm{~min}\end{array}$ & $\mathrm{x} 50$ & 59 & Real-time & Diallo et al. (2007) \\
\hline EHV5 & $\mathrm{gB}$ & $\begin{array}{l}\text { EHV5-gB-S: + ATGAACCTGACAGATGTGCC } \\
\text { EHV5-gB-AS: - CACGTTCACTATCACGTCGC }\end{array}$ & $\begin{array}{l}94^{\circ} \mathrm{C} \\
94^{\circ} \mathrm{C} \\
60^{\circ} \mathrm{C} \\
72^{\circ} \mathrm{C} \\
72^{\circ} \mathrm{C}\end{array}$ & $\begin{array}{l}5 \mathrm{~min} \\
30 \mathrm{sec} \\
45 \mathrm{sec} \\
1 \mathrm{~min} 30 \\
8 \mathrm{~min}\end{array}$ & $\mathrm{x} 50$ & 293 & $\begin{array}{l}\text { Classical } \\
\text { One step }\end{array}$ & Dynon et al.(2001) \\
\hline
\end{tabular}

+ : forward primer, - : reverse primer

* second round primers of nested PCR 
Table 3

PCR detections of herpesviruses in the tracheal washes (TW) and bronchoalveolar lavages (BAL) of the control (CTL) and pathological (PAT) groups.

\begin{tabular}{|c|c|c|c|c|c|c|}
\hline & \multicolumn{3}{|c|}{ TW } & \multicolumn{2}{|r|}{ BAL } & \multirow[b]{2}{*}{$P$ value $^{\mathrm{a}}$} \\
\hline & $\operatorname{CTL}(n=37)$ & $\operatorname{PAT}(n=259)$ & $P$ value $^{\mathrm{a}}$ & $\operatorname{CTL}(n=25)$ & $\operatorname{PAT}(n=387)$ & \\
\hline PCR target & + & + & & + & + & \\
\hline EHV-1 & $0[0 \%]$ & $4[2 \%]^{b}$ & $>0.05$ & $0[0 \%]$ & $4[1 \%]^{c}$ & $>0.05$ \\
\hline EHV-2 & $4[11 \%]$ & $85[33 \%]$ & $0.006 *$ & $9[36 \%]$ & $82[21 \%]$ & $>0.05$ \\
\hline EHV-4 & $1[3 \%]$ & $17[7 \%]$ & $>0.05$ & $1[4 \%]$ & $16[4 \%]$ & $>0.05$ \\
\hline EHV-5 & $0[0 \%]$ & $8[3 \%]$ & $>0.05$ & $0[0 \%]$ & $16[4 \%]$ & $>0.05$ \\
\hline $\begin{array}{l}\text { EHV consensus } \\
\text { PCR }\end{array}$ & $7[19 \%]$ & $112^{\mathrm{d}}[43 \%]$ & $0.004 *$ & $10[40 \%]$ & $133^{\mathrm{e}}[34 \%]$ & $>0.05$ \\
\hline
\end{tabular}

${ }^{\mathrm{a}}$ Fisher's exact test

b 11 tests were not performed on this run for EHV-1 due to insufficient quantity of biological material.

c 2 tests were not performed on this run for EHV-1 due to insufficient quantity of biological material.

* Statistically significant result

d 8 samples were sequenced as Asinine herpesvirus 5 in the PAT group.

${ }^{\mathrm{e}} 16$ samples were sequenced as Asinine herpesvirus 5 in the PAT group. 


\section{Table 4}

Association between ciliocytophthoria or epithelial cells abnormalities with the status of horses and sample type (TW or BAL)

\begin{tabular}{|c|c|c|c|c|c|}
\hline & & \multicolumn{2}{|c|}{ CTL } & \multicolumn{2}{|l|}{ PAT } \\
\hline & & + & - & + & $P$ value $^{\mathrm{a}}$ \\
\hline \multirow{2}{*}{$\mathbf{B A L}$} & $\mathrm{ECAb}$ & $0 / 25[0 \%]$ & $25 / 25[100 \%]$ & $372 / 387[96 \%]$ & 0.6 \\
\hline & $\mathrm{CCPh}$ & $0 / 25[0 \%]$ & $25 / 25[100 \%]$ & $356 / 387[92 \%]$ & 0.2 \\
\hline \multirow{2}{*}{$\mathbf{T W}$} & $\mathrm{ECAb}$ & $9 / 37[24 \%]$ & $28 / 37[76 \%]$ & $198 / 259[76 \%]$ & 1 \\
\hline & $\mathrm{CCPh}$ & $7 / 37[19 \%]$ & $30 / 37[81 \%]$ & $72 / 259[27 \%] \quad 187 / 259[73 \%]$ & 0.3 \\
\hline
\end{tabular}

$\mathrm{CTL}=$ control group PAT $=$ pathological group $; \mathrm{CPh}=$ ciliocytophthoria $; \mathrm{ECAb}=$ exfoliated epithelial cells abnormalities

${ }^{a}$ Fisher's exact test

Note: a combination of the two criteria (CCPh and/or ECAb) is not significant in TW or BAL $(0.24$ and 0.70 respectively) 


\section{Table 5}

Herpesvirus DNA detection by ciliocytophthoria or epithelial cells abnormalities in the BAL and TW

\begin{tabular}{|c|c|c|c|c|c|c|c|c|}
\hline \multirow{2}{*}{$P$ values ${ }^{\mathrm{a}}$} & \multicolumn{2}{|c|}{ EHVs } & \multicolumn{2}{|c|}{ EHV-2 } & \multicolumn{2}{|c|}{ EHV-5 } & \multicolumn{2}{|c|}{ EHV-4 } \\
\hline & TW & BAL & TW & BAL & TW & BAL & TW & $\mathrm{BAL}$ \\
\hline Ciliocytophthoria & 0.28 & $0.04 *$ & 0.39 & 0.17 & 0.31 & $0.02 *$ & 0.41 & 1 \\
\hline Epithelial cells abnormalities & 0.2 & $0.01 *$ & 0.5 & $0.007 *$ & 0.16 & 0.45 & 1 & 0.47 \\
\hline $\mathrm{CCPh}$ or ECAb & 0.30 & 0.06 & 0.33 & 0.13 & 0.52 & 0.034* & 0.59 & 1 \\
\hline
\end{tabular}

* Significant results $(P<0.05)$

${ }^{a}$ Fisher's exact test 


\section{Table 6}

Association between herpesvirus DNA detection and polymorphonuclear neutrophils cells (PMN) percentage in the TW for the control group (CTL) and the pathological group (PAT).

\begin{tabular}{|c|c|c|c|c|c|c|c|}
\hline \multirow{2}{*}{\multicolumn{2}{|c|}{$\begin{array}{c}\text { Herpesvirus } \\
\text { PMN (\%) }\end{array}$}} & \multicolumn{2}{|c|}{ EHVs } & \multicolumn{2}{|c|}{ EHV-2 } & \multicolumn{2}{|c|}{ EHV-4 } \\
\hline & & + & - & + & & + & - \\
\hline CTL & $0-20$ & 18.92 & 81.08 & 10.81 & 89.19 & 2.86 & 97.14 \\
\hline PAT & $0-20$ & 37.74 & 62.26 & 30.19 & 69.81 & 3.77 & 96.23 \\
\hline PAT & $21-40$ & 40.91 & 59.09 & 25.00 & 75.00 & 4.55 & 95.45 \\
\hline PAT & $41-60$ & 45.45 & 54.55 & 40.91 & 59.09 & 0.00 & 100 \\
\hline PAT & $61-80$ & 40.54 & 59.46 & 35.14 & 64.86 & 8.11 & 91.89 \\
\hline PAT & $81-100$ & 47.57 & 52.43 & 34.95 & 65.05 & 9.71 & 90.29 \\
\hline \multicolumn{2}{|c|}{$\begin{array}{c}\text { Cochran -Armitage } \\
\text { trend test / two-sided } P>|Z|\end{array}$} & \multicolumn{2}{|c|}{0.009} & \multicolumn{2}{|c|}{0.0165} & \multicolumn{2}{|c|}{0.0542} \\
\hline
\end{tabular}

Results for EHV-1 and EHV-5 were not significant 